\title{
CONTRIBUIÇÕES DA SOCIOLÍNGUISTICA EDUCACIONAL PARA O PROCESSO DE ENSINO-APRENDIZAGEM E AMPLIAÇÃO DA COMPETÊNCIA COMUNICATIVA DE ALUNOS DO ENSINO MÉDIO
}

\author{
LAS CONSTRIBUICIONES DE LA SOCIOLINGÜÍSTICA \\ EDUCATIVA PARA EL PROCESO DE ENSEÑANZA- \\ APRENDIZAJE Y AMPLIACIÓN DE COMPETÉNCIA \\ COMUNICATIVA DE LOS ALUMNOS DE LA ENSEÑANZA \\ SECUNDÁRIA
}

\author{
André Effgen de Aguiar ${ }^{1}$ \\ Samanta Martins Barbosa ${ }^{2}$
}

\begin{abstract}
RESUMO: Este artigo foi desenvolvido a partir de dois questionamentos que rondam o ensino de língua materna: por que os alunos se sentem estrangeiros à própria língua? $\mathrm{E}$ por que os diferentes falares são ignorados na escola? Com o propósito de enfrentar os problemas educacionais em torno dessas indagações, nos fundamentamos na Sociolinguística Educacional (BORTONI-RICARDO, 2004, 2005) a fim de apresentar uma proposta pedagógica mais sensível, promovendo uma reflexão sobre a atuação e postura dos professores e elencando a importância de uma consciência sobre as variedades linguísticas. Para isso, buscamos aporte teórico-metodológico nas reflexões de Bortoni-Ricardo $(2004,2005,2013)$ e Bagno (1999) e, no intuito de propor atividades educacionais que poderão ser utilizadas em sala de aula para tratar reflexiva e criticamente o tema variação linguística, ampliando a competência comunicativa de alunos do Ensino Médio.
\end{abstract}

PALAVRAS-CHAVE: Sociolinguística Educacional. Variação Linguística. Preconceito Linguístico. Ensino.

RESUMEN: Este artículo fue desarrollado a partir de dos cuestiones que merodean la enseñanza de lengua materna: ¿por qué los alumnos se sienten extranjeros a la propia lengua? ¿por qué las distintas maneras de hablar son ignoradas en la escuela? Con el propósito de enfrentar los problemas educacionales alrededor de estas cuestiones, nos basamos en la Sociolingüística Educativa (BORTONI-RICARDO, 2004, 2005) con el intuito de enseñar una propuesta pedagógica más sensible, promocionando una reflexión sobre la actuación y postura de los profesores y enfatizando la importancia de una conciencia sobre las variedades lingüísticas. Para eso, utilizamos como aporte teóricometodológico las reflexiones de Bortoni-Ricardo (2004, 2005, 2013) e Bagno (1999), pensando en proponer actividades educacionales que podrán ser utilizadas en el aula para tratar reflexiva y críticamente el tema variación linguiística, ampliando la competencia

\footnotetext{
1 Doutorando em Linguística Aplicada e Estudos da Linguagem na PUC-SP; Professor do Instituto Federal do Espírito Santo, Vitória (ES). E-mail: aeffgen@gmail.com.

2 Graduada em Letras-Português pelo Instituto Federal do Espírito Santo. E-mail: samanta0603@gmail.com
} 
comunicativa de los alumnos de la enseñanza secundaria. PALABRAS CLAVE: Sociolingüística Educativa. Variación Lingüística. Prejuicio Lingüístico. Enseñanza.

\section{Introdução}

As escolas e os docentes se deparam todos os dias com diferentes alunos que trazem consigo diferentes formas de falar, de diferentes culturas, bairros, cidades e até estados. Isso gera desafios, pois a aproximação do professor ao mundo do aluno se torna algo difícil e pode complicar a interação e construção do conhecimento de ambos. Gadotti (2003) afirma que o processo de aprendizagem de todo ser vivo se dá na interação, nas suas relações sociais. Assim, "para que o educador ensine com qualidade, ele precisa dominar, além do texto, o contexto" (GADOTTI, 2003, p. 48), ou seja, ele precisa conhecer o mundo em que o aluno está inserido e por meio disso provocar situações em que a construção de conhecimento seja constante, acontece no permanente devir entre os pares, participantes da situação de aula.

Todo aluno traz consigo um conhecimento prévio sobre uso da língua(gem), exemplo disso é o uso da linguagem e a estruturação da fala que mesmo crianças, não tendo nenhuma ideia do que isso seja, são capazes de formular frases de uma tal forma que é como se conhecessem a norma padrão. Aqui entra o papel da escola e do professor: organizar o que o aluno já sabe, assimilar e desenvolver esse saber alicerçado ao meio em que ele vive e capacitá-lo para se adequar linguisticamente a qualquer contexto em que esteja inserido.

Muitos professores planejam suas aulas como se estivessem baseados no antigo conceito aristotélico de que o aluno seria uma tábula rasa, ainda que, na atualidade, tal pensamento seja considerado antiquado e obsoleto. Não entendemos o porquê de uma parte dos docentes continuarem encarando a educação no século XXI dessa forma, o que nos leva a pensar que ou não conseguiram acompanhar a evolução do ensino, ou, por comodismo, se estacionaram no behaviorismo clássico, trabalhando com uma noção de estímulo-resposta, ao acreditar que ao controlar o estímulo, controlará também o comportamento do aluno, ou, ainda, permanecem baseados em um ensino mecanicista e bancário (FREIRE, 2000), o qual considera o aluno como totalmente passivo, como se o estudante fosse um receptáculo onde o professor (o único detentor de saberes) deverá depositar todo o seu conhecimento. 
Possenti (1996, p. 61) assevera que o "objetivo da escola é ensinar o português padrão, ou talvez mais exatamente, o de criar condições para que ele seja aprendido". Entretanto, pensamos que o objetivo é bem maior do que apenas ensinar a variante padrão, é preciso incentivar o aluno a refletir sobre o uso da linguagem, ser crítico acerca das incontáveis possibilidades de uso dela, não assumindo uma postura preconceituosa e préconcebida sobre as variáveis encontradas.

Em razão disso, o presente artigo busca encontrar na Sociolinguística Educacional, teoria defendida por Bortoni-Ricardo (2004, 2005) e Bagno (1999), um caminho para conduzir os alunos a pensarem a linguagem que usam pelo viés da diversidade linguística, apresentando aos alunos discursos variados, no intuito de que percebam tais possibilidades de uso, sejam elas regionais, sociais ou situacionais, tornando-os, assim, capazes de se adequarem linguisticamente a qualquer situação ou meio, ampliando a competência comunicativa por meio de reflexões continuadas sobre a própria língua. Nessa esteira, Bagno (1999) afirma que assim como um instrutor instrui seus alunos para formar bons motoristas, e não competidores da Fórmula 1; os professores devem ensinar seus alunos a fim de que se tornem bons usuários da língua escrita e falada, e não prováveis candidatos ao Prêmio Nobel de literatura.

Dessa maneira, este artigo originou-se a partir do questionamento de haver entre alunos discursos que manifestam um sentimento de inferioridade com relação à própria língua materna, com o velho estigma de que "não sabem falar direito" ou de que "não sabem falar o português". Mariani (2008) afirma que comentários como "não sei falar português direito", "mal sei falar a minha língua", "português é muito difícil” fundem um absurdo e uma evidência: "trata-se de um absurdo porque podemos perguntar como é possível alguém dizer que não sabe falar a língua materna. E como é possível que isso se mostre para o sujeito como uma verdade, uma evidência sobre si mesmo?" (MARIANI, 2008, p. 28). Como, o porquê, e de onde veio esse sentimento de que a própria língua materna está em um nível acima das suas capacidades, algo inalcançável? Tais questionamentos nos levaram a buscar um porquê para tamanha incoerência, e nos motivaram a discutir uma forma para mudar isso.

Assim, para o desenvolvimento deste artigo foi feita uma pesquisa bibliográfica para pôr em diálogo as teorias abordadas e provocar reflexões a partir desse aparato teórico. Desse modo, além de refletirmos sobre como a Sociolinguística Educacional pode contribuir para o ensino de língua materna, proporemos atividades escolares que 
auxiliem essa prática e ajudem no desenvolvimento da competência comunicativa dos alunos.

\section{Concepções de linguagem e a Sociolinguística Educacional}

Não é de agora que muitos autores discutem sobre a importância da concepção de linguagem e a sua importância para o processo de ensino-aprendizagem dos alunos. Com isso, três diferentes modos de se conceber a linguagem foram difundidos na história da língua: linguagem como expressão do pensamento, linguagem como instrumento de comunicação e linguagem como forma ou processo de interação (cf. FUZA et al, 2011).

Na primeira concepção, preconiza-se que a expressão é produzida no interior da mente dos indivíduos. Aludindo que a linguagem era tida como a tradução do pensamento e provinha de uma gramática normativa fechada que distinguia o "certo e errado", valorizava o ensino prescritivo da língua, desconsiderava as variações existentes na língua e privilegiava algumas formas linguísticas em detrimento de outras. Então, se o indivíduo não consegue pensar, logo, não será um bom escritor. Essa tendência é ultrapassada, uma vez que a mesma reduz o fenômeno linguístico a um ato racional, "a um ato monológico, individual, que não é afetado pelo outro nem pelas circunstâncias que constituem a situação social em que a enunciação acontece" (TRAVAGLIA, 1997, p. 21).

$\mathrm{Na}$ segunda concepção é abordada a linguagem como instrumento de comunicação, ou seja, é o código pelo qual todos os indivíduos se comunicam, possibilitando ao emissor transmitir uma determinada mensagem ao seu receptor. Entende-se que, se os falantes não estiverem sob um mesmo código, a comunicação não ocorreria. Porém, essa visão deixaria a linguagem presa a um sistema de código obrigatório no qual o sistema desprivilegia o conteúdo, a significação e os elementos extralinguísticos que constituem a língua. Ferdinand de Saussure (fundador do Estruturalismo) e Noam Chomsky (criador do conceito de Gramática Transformacional) ancoraram seus estudos sob essa concepção.

Saussure foi o fundador da ciência linguística com sua obra Curso de Linguística Geral (1916) e a partir de sua obra fundante definiu a língua como objeto de estudo. Sua perspectiva sobre a língua era a de um sistema homogêneo e abstrato, partilhado por uma comunidade de falantes, que ganha realidade concreta na fala. Limitava-se ao estudo sincrônico, pois abordava somente um estado da língua. Ou seja, o modo como a língua se modificava não lhe interessava. Seu objetivo era saber como era o seu funcionamento, 
num recorte de tempo, como meio de comunicação de seus falantes, com base na análise de sua estrutura e configuração normal.

Já Chomsky ia de encontro ao estruturalismo saussuriano, por este não se relacionar com a criatividade da linguagem. Com sua linha de estudo, o linguista norteamericano formulou que com um número finito de categorias e regras (competência), o locutor-ouvinte de uma língua possa gerar e interpretar um número finito de frases da língua (desempenho ou performance). Do mesmo modo, como no conceito de língua de Saussure, a competência tem caráter abstrato, enquanto o desempenho, como a fala, tem caráter concreto. De acordo com o pensamento de Chomsky,

[...] a competência consiste no conhecimento que o falante tem de um conjunto de regras que lhe permite produzir e compreender um número infinito de sentenças, reconhecendo aquelas que são bem formadas, de acordo com o sistema de regras da língua. (BORTONI-RICARDO, 2004, p. 71- grifos da autora)

Quanto a expressão "bem formadas”, é importante salientar que todas as sentenças proferidas por falantes de uma mesma língua são bem formadas, mesmo que algumas não pertençam a variante de prestígio. Então, desde que a sentença seja produzida por um falante nativo da língua que possua o conhecimento das regras básicas das variedades e estilos dessa língua, será considerada "bem formada". Assim,

[...] todo falante nativo do português, independentemente de sua posição no contínuo de urbanização e independentemente também do seu grau de monitoração estilística na produção de uma tarefa comunicativa, produz sentenças bem formadas, que estão de acordo com as regras do sistema da língua que esse falante internalizou. [...] Não se pode confundir, pois, o conceito de sentenças bem formadas, que provém da noção de competência, com a noção de "erro" que as nossas gramáticas normativas defendem. (BORTONI-RICARDO, 2004, p. 72)

Ficam, então, definidos os conceitos de competência linguística que Chomsky contrapôs ao conceito de desempenho. O primeiro é abstrato e consiste no conhecimento internalizado que o falante tem das regras para constituir uma sentença; já o desempenho, por outro lado, consiste no uso efetivo da língua pelo falante.

Em resposta a essa dicotomia criada por Chomsky, muitos linguistas tomaram-na como objeto de estudo e inúmeras críticas e reconsiderações foram realizadas a partir disso. Uma das reformulações que se destacou foi a de Dell Hymes. O sociolinguista, em 1966, notou que o conceito de competência linguística não compreendia o tópico da variação linguística. Assim, propôs um novo conceito o qual abarcava não somente as regras gramaticais presas à língua, mas também os preceitos culturais e sociais que definem a adequação da fala: a competência comunicativa. 
Para Hymes (1997 apud Bortoni-Ricardo, 2004), a competência comunicativa de um falante lhe confere a oportunidade de saber o que falar e como falar com quaisquer interlocutores em quaisquer contextos. O que Hymes trouxe de inédito em sua pesquisa foi a noção de adequação no campo da competência. Bortoni-Ricardo (2004, p. 73), refletindo sobre a competência comunicativa, assevera que, quando faz uso da língua, o falante não só aplica as regras para obter sentenças bem formadas, mas também faz uso de normas de adequação definidas em sua cultura. São essas normas que lhe dizem quando e como monitorar seu estilo.

Essa noção de competência comunicativa é fundamental quando pensamos a linguagem em seu papel interacional. Segundo Travaglia (1997, p. 23), nessa concepção de linguagem, o que o indivíduo faz ao usar a língua não é tão somente traduzir e exteriorizar um pensamento ou transmitir informações a outrem, mas sim realizar ações, agir, atuar sobre o interlocutor (ouvinte/leitor). Diferentemente das outras concepções de linguagem, essa concepção entende a linguagem como um lugar de interação humana, o lugar de constituição de relações sociais.

Contudo, o que vemos nas salas de aulas são atividades que nos parecem ainda focadas em concepções estruturalistas de língua, que tentam ensinar linguagem por meio de atividades mecânicas e sem conexão com o mundo real. Várias pesquisas versam sobre o cotidiano escolar (cf. ALONSO, 2003; GADOTTI, 1994; LUCKESI, 1996; MORIN, 2000; PATTO, 1999; SAVIANI, 1991) e evidenciam o fracasso no ensino da LP, pois, ainda, podemos afirmar que o ensino dessa disciplina, em muitas escolas, segue restrito ao ensino apenas da gramática normativa, que desconsidera o processo comunicativo, dialógico e operatório da linguagem. Desse modo, pensamos que uma análise da própria prática docente se faz necessária, pois a concepção de linguagem de que cada professor se apropria é relevante para o ensino em que ele pretende oferecer, porque é a partir dela que ele estruturará o seu fazer docente.

Embora mudanças no ensino da LP tenham ocorrido, é possível afirmar que a escola ainda não reconhece por completo a realidade heterogênea da língua, enxergandoa como um sistema único, fechado e homogêneo, cultivando a propagação da tradição gramatical que exclui as demais variantes, rotulando-as como erros ou desvios. Pela ausência de consciência e falta de reconhecimento linguístico sobre sua própria língua, dissemina-se, então, uma visão deformada e preconceituosa do que é certo e errado quanto à gramática de nossa língua. 
Por meio de pesquisas de descrição linguística, a Sociolinguística Educacional vem trabalhando junto à Educação, a fim de modificar conceitos tradicionais (e.g., ensino de metalinguagem, falar certo $\mathrm{x}$ falar errado, dicotomia oral $\mathrm{x}$ escrito, dentre outros) ligados à norma padrão da língua. Dessa forma, a fim de buscar respostas para questões educacionais dentro do mundo da escola, usaremos, neste artigo, essa teoria na intenção de auxiliar os professores a saírem do seu lugar de conforto e se arriscarem mais quanto a sua forma de ensino, pensando em sua prática docente, analisando não somente a micro realidade de sala de aula, mas considerando temas mais amplos que se inserem no contexto social maior, conciliando os aspectos micro e macro do processo.

A seguir, abordaremos os pensamentos da Sociolinguística Educacional e suas possíveis conexões com a prática de sala de aula.

\section{O que é e o que estuda a Sociolinguística Educacional? (breve panorama)}

Em meados da década de 60, um ato revolucionário surge para confrontar as limitações dos estudos da linguagem predecessoras que não consideravam a influência do meio social e do contexto na linguagem e percebiam a língua apenas como uma estrutura, dissociada de seu existir concreto nas sociedades. Desse modo, a Sociolinguística surge para investigar os fenômenos linguísticos em seu contexto social e cultural em situações reais de uso dentro de uma comunidade linguística, conectando a língua à história social dos falantes, consolidando uma concepção de linguagem essencialmente social e considerando como ponto inicial de análise a diversidade própria de uma comunidade linguística.

Para Labov ([1972] 2008), o propósito da Sociolinguística se firma na evidência de que há entre a estrutura linguística e a estrutura social uma sistemática covariação. Hymes (1997 apud Bortoni-Ricardo, 2004) apoia uma linguística mais social e constituída, perspectiva na qual não distingue os conceitos de língua e sociedade um do outro. Já Fishman (1974) opta falar em Sociologia da linguagem, pois, para ele, são importantes também questões como atitudes, crenças, estereótipos, e valores simbólicos que são adquiridos pelas variedades linguísticas para seus usuários. 
O precursor da Sociolinguística Variacionista ou Quantitativa foi William Labov e seu estudo foi firmado nos EUA. A mudança linguística foi a motivação dos estudos de Labov e foi estudando tal tema que esse linguista e outros inferiram que a variação é a condição para que a mudança linguística ocorra. Foi em 1963 que Labov publicou seu ilustre trabalho sobre a comunidade da ilha de Martha's Vineyard ${ }^{3}$, no litoral de Massachussets, que abriu caminhos para a importância dos fatores sociais na explicação da variação e da mudança linguística. Esse estudo foi marcado como a ruptura com a definição de língua advinda de Saussure. Labov relaciona em sua pesquisa fatores como sexo, idade, profissão, origem étnica e atitude ao comportamento linguístico dos vineyardenses, analisando a língua por um viés heterogêneo, correlacionado à heterogeneidade social. Desse modo, o objeto de estudo da sociolinguística é, justamente, a diversidade linguística, passível de ser observada, descrita e analisada em seu contexto social.

\section{O que propõe a Sociolinguística Educacional?}

E é com base nessa visão de língua viva, prática, efetivada no dia a dia pelos falantes, advinda dos princípios da sociolinguística, que este trabalho é embasado. Tomando consciência também de que, essa língua real não é homogênea, como exposto e proposto pelas gramáticas normativas; mas de maneira oposta, ela varia de acordo com os fatores sociais, como a intenção do falante, nível de escolaridade, idade, sexo, nível social, região, profissão, e muitos outros. Passando assim a reconhecer a língua não somente como reflexo da sociedade, mas parte dela. Esse é o contexto que esperamos que os professores reconheçam e trabalhem em sala de aula.

\footnotetext{
${ }^{3}$ Labov em 1960 deixou sua carreira como engenheiro e, ao se interessar pela linguística, passou a investigar o dialeto da ilha de Martha's Vineyard, gravando muitas conversas com os habitantes. Analisando as gravações, descobriu que cada falante manifestava uma extensa gama de pronúncias. É interessante apontar que muitos linguistas realizaram pesquisas semelhantes e chegaram aos mesmos resultados e decidiram que não havia valor no que fora descoberto. Foi então que Labov empregou uma técnica estatística simples aos dados coletados que hoje é conhecido como abordagem quantitativa. Com isso, chegou ao índice de centralização (I.C) e conseguiu mostrar que os indivíduos da ilha se diferiam substancialmente entre si no grau de centralização. Labov não se limitou apenas ao resultado da pesquisa inicial e foi além investigando o impacto social e histórico causado na comunidade nativa e os reflexos que tais mudanças tiveram sobre os moradores. Conclui-se que há três temas centrais de Labov em Martha's Vineyard: (1) A abordagem quantitativa (estatística) de variação pode revelar diferenças sistemáticas entre os indivíduos e os grupos que não seriam evidentes. (2) Uma variável linguística pode exibir estratificação social em que membros de grupos sociais distintos atribuem valores diferentes ao mesmo variável. (3) Uma mudança que está em curso se revela na forma da presença de variação.
} 
Com o intuito de propor uma outra forma de ensinar a Língua Portuguesa, trataremos de uma das subáreas da Sociolinguística denominada Sociolinguística Educacional. Esse âmbito de estudo inclina-se para a variação linguística que ocorre na LP e, por atuar sobre a realidade linguística daqueles que usam a língua considerando não somente os fatores internos à língua (fonologia, morfologia, sintaxe, semântica), mas também os fatores externos à língua (sexo, etnia, faixa etária, nível de escolaridade, classe social, região de origem, etc), percebemos que o conhecimento e estudo proveniente dessa corrente pode colaborar com a melhoria da qualidade do ensino da LP, uma vez que a função da Sociolinguística é identificar, reconhecer, analisar e aceitar as variações e mudanças como um fenômeno natural linguístico e, embora busque compreender os valores sociossimbólicos de cada variante, não dita os usos como "certo" ou "errado", e sim mostra que tais fenômenos existem e também devem ser considerados no contexto escolar.

Os estudos da Sociolinguística Educacional mostram que é possível nos aproximarmos daqueles nossos alunos que não dominam a variante de prestígio $^{4}$ ao desenvolver práticas de linguagem em uso que produzam mais sentido, fazendo-os não mais se sentirem estrangeiros à própria língua e dando-lhes acesso para apoderarem-se das regras linguísticas que gozam de prestígio, enriquecendo seu repertório linguístico, permitindo que aprendam a se comportarem linguisticamente em diversos cenários comunicativos e linguísticos sem que nada disso implique a desvalorização de sua própria variedade linguística, adquirida nas relações sociais dentro de sua comunidade (BORTONI-RICARDO, 2004, p. 9).

A variação linguística (VL) sempre existiu, portanto, quando falamos sobre a LP, entendemos que ela se constitui de muitas variedades. À medida que a necessidade de se compreender a língua como um sistema heterogêneo foi crescendo, documentos como os Parâmetros Curriculares Nacionais (PCNs, 1997) e atualmente a Base Nacional Comum

\footnotetext{
4 Aqui, mais do que afirmar que a variante padrão é a que possui prestígio em nossa sociedade, precisamos problematizar esse prestígio. Essa noção de prestígio é atribuída socialmente, por isso é importante destacar a noção de estratificação social que, segundo Labov ([1972] 2008), é o produto da diferenciação social e da avaliação social. Isso implica dizer que, no entender desse autor, "os mecanismos usuais da sociedade produziram diferenças sistemáticas entre certas instituições ou pessoas, e que essas formas diferenciadas foram hierarquizadas em status ou prestígio por acordo geral" (LABOV, 2008, p. 65). Logo, sujeitos de determinada estratificação social podem usar a mesma variedade da língua. Os usos das variedades linguísticas, assim, acompanham as estratificações da sociedade. Com isso, percebemos a relação inseparável entre língua e fatores socioculturais. Coadunando com essa visão, Milroy (2011) comenta que, de fato, as variedades linguísticas não têm prestígio em si mesmas, mas o adquirem quando seus falantes têm prestígio elevado, porque "o prestígio é atribuído pelos seres humanos a determinados grupos sociais e a objetos inanimados ou abstratos" (MILROY, 2011, p. 53).
} 
Curricular (BNCC, 2017) de Língua Portuguesa revisam a visão de língua, apontando sua heterogeneidade e passam a dar orientações e suporte para o trabalho da VL em sala de aula. Os PCNs (1997) orientavam os docentes sobre a importância de trabalhar a diversidade linguística e assumiram que a língua é um sistema heterogêneo e variável que sofre inúmeras influências de fatores externos, afirmando que

\begin{abstract}
no ensino-aprendizagem de diferentes padrões de fala e escrita, o que se almeja não é levar os alunos a falar certo, mas permitir-lhes a escolha da forma de fala a utilizar, considerando as características e condições do contexto de produção, ou seja, é saber adequar os recursos expressivos, a variedade de língua e o estilo às diferentes situações comunicativas: saber coordenar satisfatoriamente o que fala ou escreve e como fazê-lo; saber que modo de expressão é pertinente em função de sua intenção enunciativa, dado o contexto e os interlocutores a quem o texto se dirige. A questão não é de erro, mas de adequação às circunstâncias de uso, de utilização adequada da linguagem. (BRASIL, 1997, p.31 - grifos nossos).
\end{abstract}

Da mesma forma a BNCC (2017) reconhece a variação linguística enquanto fenômeno inerente à língua. Na área de Linguagens, especificamente no componente curricular Língua Portuguesa, o trabalho com a variação linguística é ressaltado como um dos seis objetivos gerais da Educação Básica. Nessa esteira, a BNCC assevera que:

compreender que a variação linguística é um fenômeno que constitui a linguagem, reconhecendo as relações de poder e as formas de dominação e preconceito que se fazem na e pela linguagem e refletindo sobre as relações entre fala e escrita em diferentes gêneros, assim como reconhecer e utilizar estratégias de marcação do nível de formalidade dos textos em suas produções. (BRASIL, 2017, p.98 - grifos nossos).

A BNCC também ressalta as relações entre fala e escrita em diferentes gêneros, isto é, a adequação linguística de acordo com o contexto interacional. É válido destacar que o documento afirma que as relações de poder e as formas de dominação e preconceito se fazem na e pela linguagem, ou seja, conceitos caros para a variação linguística, especificamente no que se refere ao preconceito linguístico, uma vez que os atos discursivos instauram estas relações de poder entre os interlocutores, como também as formas de discriminação em razão das escolhas linguísticas. Partindo dessas considerações, o documento assegura o trabalho desse fenômeno como um dos objetivos da Educação Básica, a qual engloba desde a Educação Infantil até o Ensino Médio.

Apresentada a base teórica de nosso estudo, nosso objetivo com a próxima seção é estabelecer a interconexão entre a teoria e prática de sala de aula, articulando nossa proposta de trabalho à noção de práxis (VYGOTSKY, 2007), tentando demonstrar como teoria e prática devem funcionar em um continuum ininterrupto no fazer docente. 


\section{Sociolinguística Educacional e sala de aula}

Para trabalhar, então, a Sociolinguística Educacional em sala de aula é necessário que o professor introduza, ao mesmo tempo, o respeito e aceitação pelas variedades linguísticas dos falantes e, por outro lado, uma prática de ensino cujo objeto de estudo seja a própria linguagem do aluno (verbal e não verbal). O que também não significa ignorar o português padrão, uma vez que este é, ainda, a variante de prestígio de nossa sociedade.

Ensinar sem desprezar produções textuais, verbais e não verbais, que contenham variação, não significa que é assim e deve ser assim, mas sim que estamos atuando sem preconceito linguístico e agindo de forma reflexiva, com sensibilidade e consciência para com o nosso aluno.

Dessa maneira, buscamos apoio em Bortoni-Ricardo (2005, p. 130) que propõe seis Princípios Fundamentais para a Implementação da Sociolinguística Educacional. Vejamos, então, os princípios propostos para a implementação da Sociolinguística Educacional:

Quadro 1: Princípios da Sociolinguística Educacional

\section{PRINCÍPIOS DA SOCIOLINGUÍSTICA EDUCA CIONAL}

a influência da escola na aquisição da língua não deve ser procurada no dialeto vernáculo dos falantes, mas em seus estilos formais, monitorados. É no campo da linguagem monitorada que as ações de planejamento linguístico têm influência. Assim, a Sociolinguística tem como objetivo oferecer ao aluno conhecimento e habilidade nas variedades orais e escritas de prestígio, para que ele tenha acesso a diferentes práticas da cultura letrada.

o objetivo da escola estudar as variações associadas à avaliação negativa pela sociedade não é inferiorizar o aluno que tem mais variantes em seus vernáculos, mas, sim, fazê-lo ter consciência dos valores sociossimbólicos de tais variantes.

inserção da variação sociolinguística na matriz social. $\mathrm{O}$ ensino das variedades de prestígio na escola não é necessariamente fonte de conflito, embora possa ser fonte de discriminação das crianças falantes de variedades populares. Para superar essa barreira, propõe-se que os professores desenvolvam uma pedagogia culturalmente sensível.

os estilos monitorados da língua são reservados à realização de eventos de letramento em sala de aula. Em lugar da dicotomia entre "português culto" e "português ruim", institui-se na escola a dicotomia entre letramento e oralidade (Bortoni-Ricardo, 1995); a descrição da variação na Sociolinguística Educacional não pode ser dissociada da análise etnográfica e interpretativa do uso da variação em sala de aula. O ponto de partida da Sociolinguística Educacional não é a descrição da variação por si, mas sim 
a análise minuciosa do processo interacional, na qual se avalia o significado que a variação assume.

o processo de conscientização crítica dos professores e alunos quanto à variação e à desigualdade social que ela reflete. Nesse processo, é necessário que o professor não se limite a transmitir informações técnicas, que são produto da pesquisa acadêmica, mas que se estabeleça um efetivo diálogo com o professor por meio de pesquisa, que o enriqueça e o torne apto a promover uma autorreflexão e uma análise crítica de suas ações.

Fonte: Bortoni-Ricardo (2005)

Pensamos que para trabalhar nessa perspectiva educacional e atender a esses princípios em sala de aula, o professor precisa atuar em coautoria ${ }^{5}$ com seus alunos, em uma relação menos hierarquizada e com interações claras e negociadas e, por essa razão, é imprescindível que ele explique com cuidado ao aluno as diferentes formas de uso da linguagem, ouça, entenda e analise as diferentes manifestações de linguagens trazidas pelos alunos, mostrando a importância da variante de prestígio, não como algo incontestável, mas para provar que a língua é viva e, com o tempo, ela muda, se transforma. O desafio é grande, porém não é impossível.

E não basta somente o professor colocar em prática pressupostos da Sociolinguística Educacional, é fundamental uma nova postura, uma mudança na forma de ensino da LP como língua materna na sala de aula. E isso não deve ser visto como um novo conteúdo de livro didático que fará parte de um plano de aula para um dia específico; significa quebrar um paradigma, não somente sobre ensinar a LP, mas de por que ensinar, como ensinar, para que e para quem ensinar a LP.

Seguimos o artigo, apresentando as questões metodológicas que embasaram e nortearam o desenvolvimento desta pesquisa.

\section{Questões metodológicas}

$\mathrm{O}$ artigo em questão trata-se de uma pesquisa bibliográfica, de cunho qualitativo que visa refletir sobre a Sociolinguística Educacional e conectá-la com a prática de sala

\footnotetext{
5 Kleiman (2006) afirma que pensar na posição do professor como mediador é hierarquizante, pois, dessa forma, ele atuaria como aquele que arbitra, colocando-se num papel intermediário entre dois (ou mais) interessados, o que não colaboraria para a construção conjunta de conhecimentos. Nesse mesmo trabalho, ela nos apresenta a figura do professor como coautor, que julgamos ser uma proposta que se encaixa muito bem na perspectiva de trabalho com a Sociolinguística Educacional. A autora coloca o professor e aluno na posição de agente de letramento, de um agente social, e afirma que "os agentes sociais são ativos, não passivos" (p.86), por isso, quando os indivíduos se engajam em ações sociais para a transformação, eles participam do processo no sentido mais completo e, colaborativamente, atuam como coautores das experiências compartilhadas e do conhecimento produzido.
} 
de aula. Nesse intuito formulamos atividades que pretendem ir além de questionários a serem aplicados em sala de aula, pois possuem a intenção de fazer com que professores e alunos reflitam criticamente sobre o tema e sua relevância social.

Os textos escolhidos para a atividades são contemporâneos, extraídos de páginas de internet e representam a materialidade de algum tipo de polêmica social que, de alguma forma, envolveu o tema Variação Linguística e acabou demonstrando a interpretação da sociedade em relação ao tema, sempre baseada no senso comum: de que a língua é homogênea, de que devemos utilizar o português padrão e que existe certo e errado no uso da língua.

As atividades propostas vão na contramão do senso comum, nosso intuito é causar uma ruptura nesse pensamento estereotipado sobre língua(gem) entranhado em nossa sociedade. Dessa maneira, a abordagem dos textos é feita por meio de questões que incitam a reflexão sobre a heterogeneidade da língua, bem como sobre os fatores sóciohistóricos e culturais que devem ser levados em consideração, permitindo compreender a variação e a concorrência de formas linguístico-discursivas em um contexto sociocultural não estagnado.

Devido à linguagem e termos utilizados na construção dos enunciados dos exercícios, recomendamos que as atividades aqui propostas sejam utilizadas em turmas do Ensino Médio. Nossa intenção não é tratar o tema Variação Linguística como uma unidade curricular ou como uma mera temática do currículo, pelo contrário, propomos que tal temática seja tratada de forma dispersa ao longo das séries do ensino médio, não sendo abordada de forma metalinguística, em que o ensino se dará focado somente nos fatores linguístico-textuais, mas para além disso, vinculando o tema variações linguísticas a questões/problemas sociais de notável relevância que possam ser discutidos e refletidos de forma crítica em sala de aula.

Para organizar o material, iniciamos as atividades com um quadro-síntese que visa orientar os professores antes da sua utilização, informando sobre os objetivos das atividades, quais assuntos serão abordados a partir dos textos e estabelecendo a conexão das atividades propostas com os Princípios da Sociolinguística Educacional (BORTONIRICARDO, 2005), apresentados na seção 4 deste artigo. Também vale frisar aqui que, seguindo a perspectiva socio-histórico e cultural (VYGOTSKY, [1934] 2007) utilizada na construção e abordagem do tema aqui proposto, a cada atividade, pensando o texto como prática social, propomos a produção de textos a partir de gêneros textuais que se 
conectam com a temática que está sendo explorada, como anúncio publicitário, editorial e podcast.

A seguir, discutimos nossa proposta de forma mais detalhada e apresentamos as propostas de atividades construídas.

\section{Mãos à obra: propostas de atividades}

Diante às teorias e reflexões expostas, seguiremos com algumas sugestões de atividades. Cabe frisar aqui que não pretendemos propor um modelo a ser seguido à risca pelos professores. Nossa intenção, entendendo a educação como um processo sóciohistórico e situado (SIGNORINI, 2006), é apresentar um caminho para a reflexão docente sobre a inclusão do ensino da variação linguística no cotidiano da sala de aula e de demonstrar a importância de se trabalhar com os mais variados gêneros possíveis, pensando o texto como prática social e representante das mais diversas linguagens utilizadas por nossa sociedade.

Para trabalhar na perspectiva da Sociolinguística Educacional, é necessário partir do pressuposto de que a língua é viva e mutável, podendo assim variar de acordo com a idade, grau de escolarização, o meio em que o falante está inserido ou situação. Assim se estabelece a importância de tomar a variação linguística como princípio do desenvolvimento dessas atividades, a fim de que nelas se percebam a preocupação em orientar o aluno a refletir, identificar, conscientizar, respeitar as diferentes formas em que a língua se realiza, considerando, desse modo, de acordo com Bortoni-Ricardo (2005), as três possibilidades de uso da linguagem: regional, social e situacional.

Na primeira possibilidade de uso, as variações sofrem influência do local onde os falantes vivem. Isso ocorre porque as regiões detêm diferentes culturas e hábitos. Podemos representá-la com os falares rurais, por exemplo, como comunidades bem mais interioranas ou aquelas que sofreram influência pelo meio urbano ou pela mídia. A segunda possibilidade de uso, denominada social, realiza-se por meio de hábitos e cultura de diferentes grupos sociais. Nesse caso, a variação acontece porque a forma como esses grupos atuam e seus conhecimentos se diferem dos outros são bem característicos. As gírias são um exemplo ou até mesmo os jargões de um determinado grupo profissional. A terceira possibilidade abrange os mais espontâneos usos da língua até os mais rebuscados e que demandam um maior monitoramento do falante, determinando, assim, usos menos monitorados (mais informais) até os mais formais (mais monitorados). 
É dever da escola, então, munir os alunos de atividades linguísticas que os conscientizem a se adequarem linguisticamente às diferentes situações de comunicação, garantindo-lhes autonomia social e cidadania plena. Para isso, precisamos de

\begin{abstract}
uma escola consciente de seu papel na luta contra as desigualdades sociais e econômicas e, que, por isso, assume a função de proporcionar às camadas populares, através de um ensino eficiente, os instrumentos que lhes permitam conquistar mais amplas condições de participação cultural e política e de reivindicação social. (SOARES, 2001, p. 73)
\end{abstract}

Pensando em auxiliar na construção dessa escola que preza pelo desenvolvimento da competência comunicativa dos alunos, com fins de inclusão social e de diminuição de desigualdades, propomos as seguintes atividades apresentadas abaixo, no intuito de refletir, discutir e sistematizar em sala de aula temas referentes ao ensino da Variação Linguística. Mencionamos que tais atividades não possuem caráter linear, não estão dispostas em forma de sequência, ou seja, uma não é pré-requisito da outra, podendo o professor trabalhá-las na íntegra, utilizar uma e não outra, além de ter toda a liberdade para fazer adaptações nas atividades e nos textos escolhidos.

Antes de aplicar as atividades propostas aqui, os professores precisam trabalhar à exaustão os assuntos referentes ao tema Variação Linguística, como: preconceito linguístico e o seu combate; adequação linguística; desmistificar a ideia de que existe um falar certo e um errado; português padrão e não-padrão, a importância e os usos; discurso formal e informal; noção de contextos discursivos; tipos de variações linguísticas e suas implicações sociais e problematizar, por meio da reflexão sobre a língua, o porquê de ainda nos ambientes escolares e nas aulas de Língua Portuguesa ser recorrente a associação de que saber a língua materna é saber e dominar a variante de prestígio.

Registramos ainda que, intencionalmente, todas as atividades, ao seu final, propõem a produção de um gênero textual. Pedimos aos professores que não encarem a proposta de produção de texto apresentada como uma proposta mecânica, pois acreditamos no uso do texto em sala de aula como prática social (AGUIAR, 2020; KLEIMAN, 2006), fazendo com que

a produção de textos na escola esteja de acordo com nossa representação do real, vinculada ao contexto social, atendendo, assim, aos diversos objetivos a serem alcançados por meio da interação escrita. Trabalhando a produção de textos na escola nessa perspectiva de prática social, o ato de escrever textos se transforma em uma atividade social que não se reduz à elaboração de um texto oral ou escrito (produto privilegiado pela escola), já que amplia a noção de escrita, contextualizando-a, dando razões reais ao aluno para produzir, o que difere muito da simples razão escolar de aprender o gênero. (AGUIAR, 2020, p. 153) 
Dessa maneira, é importante que o professor faça associações entre a temática do conteúdo estudado com o gênero a ser produzido, no intuito de mostrar aos alunos sua estrutura, sua função comunicativa, bem como sua relevância social, prevendo atividades de produção que vão além da mera escrita de textos e contemplem outras etapas como correção, reescrita e circulação dos textos produzidos, trabalhando, assim, a produção de textos na escola como um processo (AGUIAR, 2020).

Feitas as devidas considerações, vamos às atividades propostas:

\section{ATIVIDADE 1}

Esta atividade versa sobre o tema variação linguística, dando ênfase ao entendimento do preconceito linguístico e o porquê de muitos falantes ainda se considerarem estrangeiros a própria língua. A ideia é que o conteúdo seja aproveitado para alunos do ensino fundamental ao ensino médio, uma vez que muitas crenças preconceituosas são propagadas desde a infância. Nesta atividade, é importante evidenciar a importância do ensino da variante padrão, porém, enfatizando que não há um falar "certo" ou "errado", e sim a existência de variedades linguísticas e que, na sociedade, alguns falares são mais valorizados e outros não.

Ao final do trabalho, propomos a construção de um movimento social na escola: uma campanha contra o preconceito linguístico. Para isso, após discutir o tema com os alunos, a partir da produção de anúncios publicitários, sugerimos engajar os alunos na luta contra a estigmatização por meio da língua.

Após a inserção do aluno no contexto das diferentes formas de linguagem (variações), vamos trabalhar o uso regional e social da linguagem e os princípios 2, 3 e 5 apresentados por Bortoni-Ricardo (2005).

1. Leia a notícia': "Médico debocha de paciente na internet: 'Não existe peleumonia'7",

\footnotetext{
6 Para ler os textos utilizados nas atividades, basta clicar nos links disponíveis nas notas de rodapé ou apontar a câmera do seu celular para o QR Code disponibilizado ao lado da imagem.

7 Texto disponível em http://g1.globo.com/sp/campinas-regiao/noticia/2016/07/medico-debocha-depaciente-na-internet-nao-existe-peleumonia.html
} 


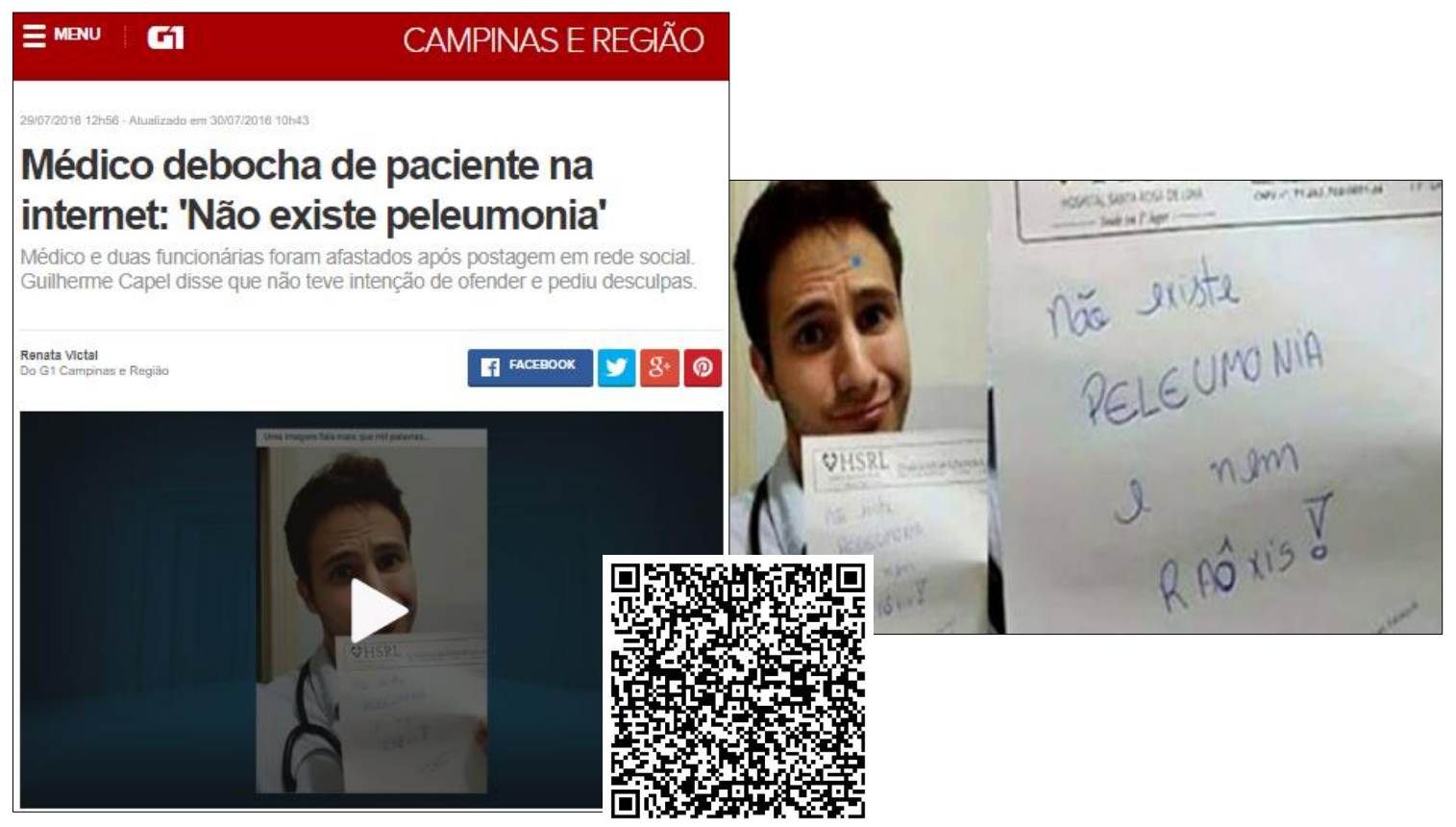

2. O médico em questão escreve duas palavras que causaram polêmica em um receituário: peleumonia e raôxis. Quem utilizou essas palavras e em que contexto?

3. Tudo se passou em um contexto de consulta médica. Pensando nos termos de adequação e competência comunicativa (assuntos já debatidos em aula) como "deveria" ser o discurso utilizado nesse contexto?

4. Refletindo socialmente, nesse caso que estamos analisando, o que levaria uma pessoa a não monitorar sua fala em determinado contexto (consulta médica) e utilizar tais termos?

5. As variedades linguísticas evidenciadas trazem marcas sociais e de regionalismo. Essas variações causariam prejuízo na compreensão entre médico e paciente? Por quê?

6. Como você julga a atitude do médico? Depois de nossa aula de variação linguística, qual conselho você daria para ele?

7. Falamos hoje de preconceito linguístico. O caso analisado na aula é um típico caso de preconceito. Rir, debochar da maneira de falar de uma pessoa pode causar transtornos e polêmicas, como vimos no caso do médico e do mecânico. Pensando no seu cotidiano, dê outros exemplos de situações em que ocorre preconceito linguístico.

8. Na reportagem lida, encontramos o trecho: "o médico havia atendido o mecânico José Mauro de Oliveira Lima, 42 anos, que estudou até o segundo ano do ensino fundamental e não sabe como falar corretamente algumas palavras". Resgatando os 
conhecimentos construídos na aula, podemos perceber que há um problema no trecho evidenciado. Encontre-o e comente.

9. Após toda polêmica vir a público, a também médica Júlia Rocha, postou em suas redes sociais o texto abaixo ${ }^{8}$, fazendo clara referência à atitude do médico do interior de SP.

Júlia Rocha
há 11 horas
EXISTE PELEUMONIA.
mostra. Disintiria, quebranto, mal olhado, impingi, cobreiro, vento virado,
ispinhela caída. Eu tô aqui pra mode atestá. Quem sabe o que tem é quem
sente. E eu quero ouvir ocê desse jeitinho. Mode a gente se entendê. Por
que pra mim foi dada a chance de conhecê as letra e os livro. Pra você, só
deram chance de dizê.
Pode dizê. Eu quero ouvir.
It 36 mil $646 \rightarrow 20$ mil

a) O que você tem a dizer sobre a linguagem utilizada por Júlia em sua postagem?

b) Com qual intenção ela faz uso de tal discurso?

c) O que o uso dessa linguagem revela sobre a médica Júlia?

d) Comparando a atitude dos dois profissionais por meio da intenção e da linguagem utilizada, o que podemos dizer sobre eles?

10. Após ler a reportagem e participar das discussões em sala de aula, podemos perceber como o preconceito linguístico pode machucar uma pessoa e ser prejudicial para a sociedade. Vamos agora começar em nossa escola uma campanha contra o preconceito linguístico. Sua missão é: produza um anúncio publicitário (vídeo, panfleto, outdoor) conscientizando a comunidade escolar sobre os malefícios desse tipo de preconceito e incentivando a não praticá-lo.

\section{ATIVIDADE 2}

Discutiremos o uso social e situacional e abordaremos os princípios 2,3 e 6 de Bortoni-Ricardo. A forma como falamos pode variar de acordo com o meio ao qual estamos inseridos ou a situação de comunicação, podendo variar do uso mais formal ao informal. Vamos falar nesta atividade um pouco sobre dialeto e contextos de uso.

\footnotetext{
8 Texto extraído de https://www.em.com.br/app/noticia/gerais/2016/07/30/interna_gerais,789264/peleumonia-medicamineira-resposta.shtml
} 
Realizar a leitura da reportagem “'Acuenda o pajubá'?': Conheça o 'dialeto secreto' utilizado por gays e travestis".

Nesta proposta, trabalharemos com a noção de dialeto, problematizando-o a partir de sua vinculação com preconceito sofrido pela população LGBTQI+. Conectando o tema estudado à sociedade em que vivemos, propomos, no final da atividade, a produção de um editorial jornalístico, para que os alunos possam posicionar-se perante o tema e para que esse seja alvo de debates em sala de aula.

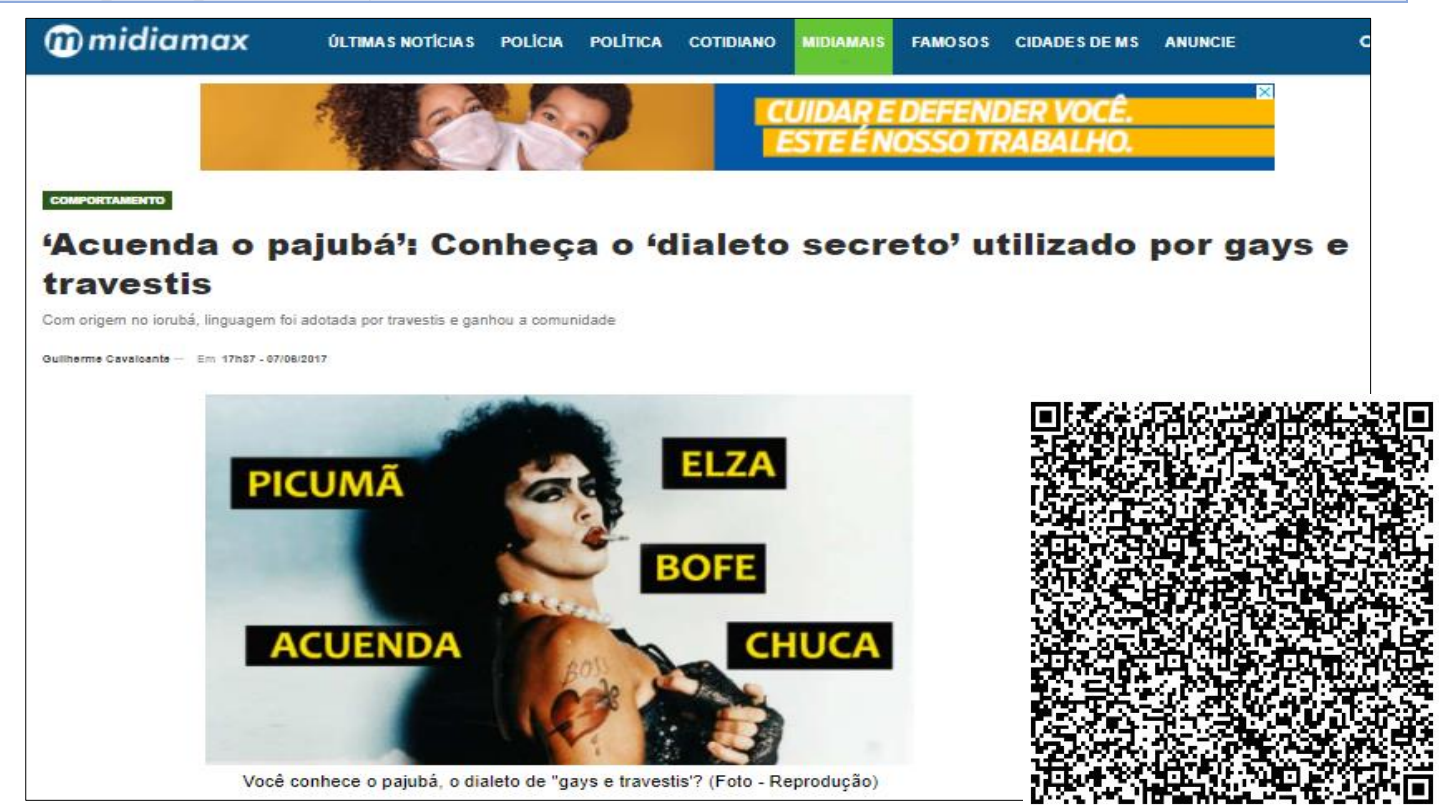

1. Historicamente, qual é a origem do Pajubá ${ }^{10}$ ?

2. Que grupo social faz uso desse dialeto e por que ele começou a ser utilizado?

3. O texto traz uma explicação social e histórica sobre a origem do Pajubá (que você já sintetizou na questão 1). Quais relações podemos estabelecer entre o dialeto Pajubá, o grupo social que o utiliza e a sua origem histórica?

\footnotetext{
9 Texto disponível em https://www.midiamax.com.br/midiamais/comportamento/2017/acuenda-o-pajubaconheca-o-dialeto-secreto-utilizado-por-gays-etravestis\#: : :text=Com\%20origem\%20no\%20iorub\%C3\%A1\%2C\%20linguagem,travestis\%20e\%20gan hou $\% 20 \mathrm{a} \% 20$ comunidade\&text $=\% \mathrm{E} 2 \% 80 \% 9 \mathrm{CNha} \% \mathrm{C} 3 \% \mathrm{AD} \% 2 \mathrm{C} \% 20 \mathrm{amap} \% \mathrm{C} 3 \% \mathrm{~B} 4$ !\&text=Se $\% 20 \mathrm{si}$ m\%2C\%20\%C3\%A9\%20porque\%20voc\%C3\%AA,das\%20palavras\%2C\%20principalmente\%20pela\% 20internet

${ }_{10}$ É importante registrar aqui que o texto escolhido para esta aula, em seu formato original, apresenta 3 vídeos que abordam o tema do dialeto Pajubá. Optamos em fazer uma adaptação do texto, não utilizando os vídeos, pois os dois primeiros vídeos, a nosso ver, apresentam uma linguagem imprópria, de cunho sexual, não sendo adequado para discussão sobretudo com séries do ensino fundamental e o terceiro vídeo apresenta uma estereotipação da comunidade gay, representando-a como caricatura e apresentando um discurso repleto de preconceitos linguísticos, os quais queremos combater com essas atividades.
} 
4. O nosso jeito de falar pode revelar de onde somos ou se pertencemos a um determinado grupo social. Comente a afirmação com base no texto lido.

5. Na reportagem, o advogado tributarista Márcio Batista diz ser adepto do uso das expressões do Pajubá. Ele afirma que: “É claro que não vou falar durante uma audiência ou numa reunião, mas na firma, com meus colegas de trabalho, eu falo de 'acué' o tempo inteiro", brinca. "A gente tem que ter cuidado de falar outras palavras porque hoje o pessoal já entende, né? Ta na internet, tem até dicionário..."

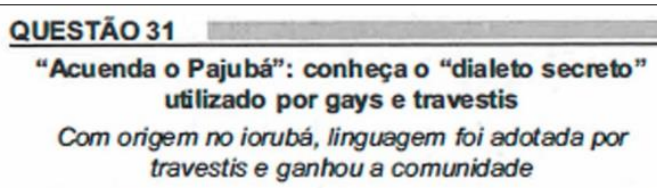

"Nhai, amapô! Não faça a loka e pague meu acué, deixe de equê se não eu puxo teu picumăl" Entendeu as palavras dessa frase? Se sim, é porque você manja alguma coisa de pajubá, o "dialeto secreto" dos gays e travestis.

Adepto do uso das expressões, mesmo nos ambientes mais formais, um advogado afirma: "É claro que eu não vou falar durante uma audiência ou numa reunião, mas na firma, com meus colegas de trabalho, eu falo de 'acué' o tempo inteiro", brinca. "A gente tem que ter cuidado de falar outras palavras porque hoje o pessoal já entende, né? Tá na internet, tem até dicionário...", comenta.

o dicionário a que ele se refere é o Aurélia, a dicionária da língua afiada, lançado no ano de 2006 e escrito pelo jornalista Angelo Vip e por Fred Libi. Na obra, há mais de 1300 verbetes revelando o significado das palavras do pajubá.

Não se sabe ao certo quando essa linguagem surgiu, mas sabe-se que há claramente uma relação entre o pajubá e a cultura africana, numa costura iniciada ainda na época do Brasil colonial.

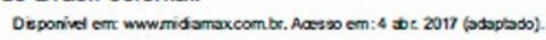

Da perspectiva do usuário, o pajubá ganha status de dialeto, caracterizando-se como elemento de patrimônio linguistico, especialmente por

(4) ter mais de mil palavas conhecidas.

(B) ter palavras diferentes de uma linguagem secreta.

(C) ser consolidado por objetos formais de registro.

(1) ser utilizado por advogados em situações formais.

(e) ser $\infty$ mum em conversas no ambiente de trabalho. a)

"É claro que não vou falar durante uma audiência ou numa reunião". Em relação ao tema variação linguística, comente a afirmação do advogado.

b) Dentre os conceitos que estamos estudando em relação à adequação de discursos, o que nos revela a atitude do advogado?

6. "Tá na internet, tem até dicionário..., comenta. [...] O dicionário a que Marcio se refere é o 'Aurélia, o dicionário da língua afiada', lançado no início dos anos 2000." O que o fato de ser, de certa forma, dicionarizado nos mostra sobre o dialeto Pajubá?

7. Em 2018, a matéria lida para esta atividade foi adaptada e transformou-se em uma questão do ENEM.

a) Resolva a questão proposta pelo ENEM.

b) $\mathrm{Na}$ época da realização da prova, a inserção dessa questão em um exame nacional causou muita polêmica na sociedade brasileira. Pesquise e responda: que polêmica foi essa?

c) Em relação ao dialeto, o que o surgimento de tal polêmica nos mostra?

d) Usando o estudo de variação linguística, entendendo a língua como viva e sabendo da importância dos dialetos, produza um editorial para um jornal da cidade que abarque a polêmica causada pela questão e que deixe claro seu 
posicionamento em relação à atitude dos brasileiros que se manifestaram contra ou ficaram espantados com o uso do texto na prova.

\section{ATIVIDADE 3}

Nesta atividade, analisaremos a reportagem televisiva "Homem e adolescente ficam feridos após tiroteio em Vila Velha, ES ${ }^{11}$ ". É importante direcionar os alunos a se atentarem nas interações que acontecem durante a reportagem e para a adequação da fala da entrevistada ao narrar os fatos. Por saber que está sendo gravada, ela inicia a história com a fala mais monitorada, formal, e, ao falar do irmão, se desestabiliza e a marca da informalidade aparece.

Os princípios 1, 5 e 6, de Bortoni-Ricardo, serão abordados aqui, uma vez que a autora enseja a necessidade de verificarmos as variações por meio das falas monitoradas, oferecendo ao aluno meios de flutuar entre o formal e informal; o processo interacional deverá ser analisado e o professor, de forma crítica e reflexiva, trará à tona a desigualdade social observada na entrevista, conduzindo também os seus alunos à autorreflexão e a participarem da análise. O objetivo desta atividade é levar os alunos a observarem que, de acordo com a situação que o falante se encontra, o índice de monitoramento da fala dele dependerá da situação/meio em que ele estará inserido, gerando usos mais monitorados ou menos monitorados da língua.

$\mathrm{Na}$ intenção de aprofundar ainda mais a questão das desigualdades sociais e suas implicações no uso da língua, propomos ao final desta unidade a produção de podcasts em que os alunos discutirão: “que língua(s) falamos?", dando-nos a alternativa de ampliar o debate para além das paredes da sala de aula, através da oportunidade de divulgação dos textos produzidos em redes sociais (da escola e/ou dos alunos).

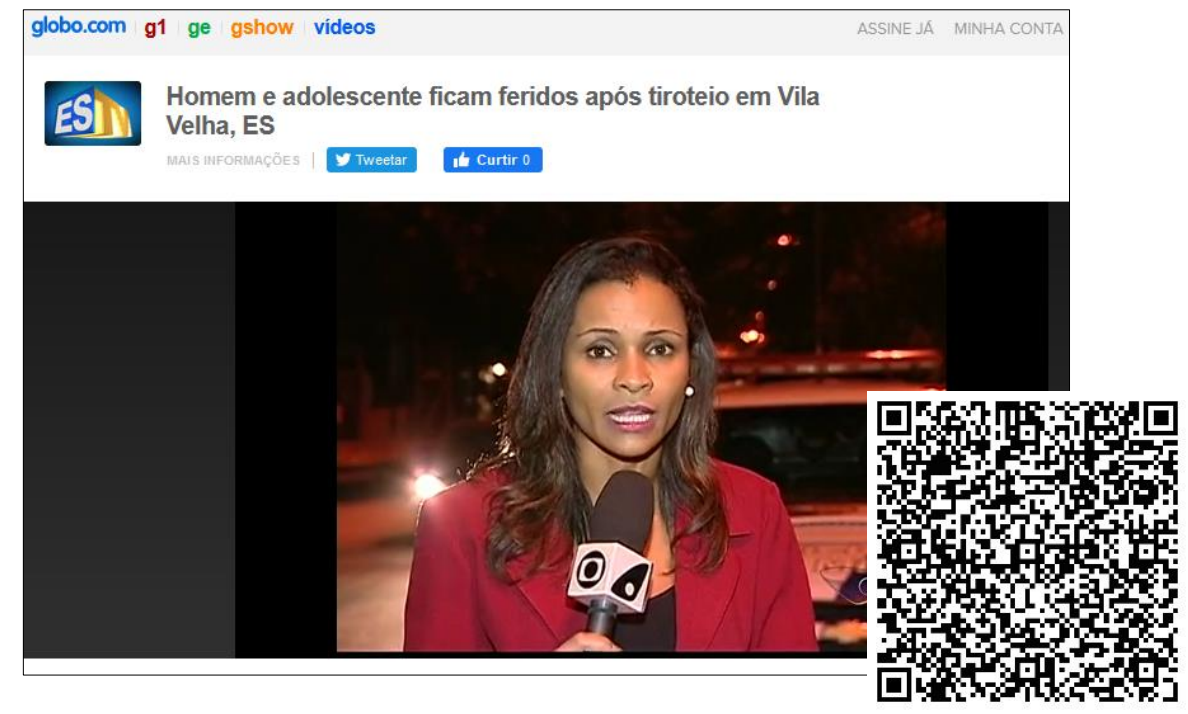

1. Observando a entrevista, qual é a diferença entre o discurso da repórter e o discurso da irmã do jovem baleado? Explique.

2. Por que você acha que existe essa diferença discursiva? Quais seriam os motivos?

11 Texto disponível em http://g1.globo.com/espirito-santo/estv-1edicao/videos/v/homem-e-adolescenteficam-feridos-apos-tiroteio-em-vila-velha-es/2552746/ 
3. Levando em consideração que o contexto enunciativo em questão é uma entrevista televisiva, qual dessas duas pessoas tem o discurso mais adequado à ocasião? Explique.

4. Em qual momento a fala deixa de ser monitorada pela entrevistada? Por que você acha que isso acontece?

5. Encontre no discurso da entrevistada, marcas linguísticas de variação social e discurso informal.

6. Durante a entrevista, os participantes se referem a um mesmo grupo (moradores da localidade) utilizando termos diferentes: repórter $\rightarrow$ os moradores; entrevistada $\rightarrow$ us pessoal; policial $\rightarrow$ o popular. Reflita e comente: por que esse fenômeno acontece?

7. Pense na linguagem/discurso que você utiliza em seu dia a dia, com amigos, com a família, etc. O que tem em comum o seu discurso com o discurso da entrevistada? Por que você acredita que ocorrem essas semelhanças ou diferenças nos discursos de falantes de uma mesma língua?

8. Depois de todo o conteúdo estudado, façam trios e produzam e gravem um podcast que aborde a seguinte discussão: "Falamos a mesma língua? O Português é uma língua única e homogênea?" Vocês podem fazer a gravação em formato de entrevista, de debate ou de bate papo entre especialistas. Utilizem os conhecimentos construídos durante as aulas e sejam criativos.

\section{Considerações finais}

Neste artigo, buscamos apresentar uma proposta de trabalho com base na Sociolinguística Educacional, a fim de que a escola e os professores reconheçam o seu papel de agentes de mudança para combater o preconceito linguístico, esperando que os alunos não mais se sintam estrangeiros à própria língua, evidenciando os usos linguísticos e a importância de que eles aprendam a se adequar linguisticamente às situações em que estiverem inseridos, ampliando, assim, sua competência comunicativa.

O tema e as atividades produzidas para este artigo visam contribuir para o desenvolvimento das habilidades sociais e comunicativas dos alunos. Dessa maneira, a Sociolinguística Educacional consolida a visão de que a variante de prestígio em sala de aula deve e precisa ser ensinada, entretanto, é fulcral que o professor saiba conviver, identificar, analisar e valorizar as diferentes interações linguísticas, fazendo com que o 
aluno reflita e assimile que a língua não será aprendida por meio de um ensino fechado e engendrado de regras, pois ela é viva, plural, mutável, heterogênea.

Destarte, esperamos, com as atividades desenvolvidas, ter discutido apropriadamente o tema variações linguísticas, seus usos e a sua importância para a elevação da autoestima dos alunos, demonstrando-lhes que todos nós podemos ser, sim, usuários competentes da nossa língua materna.

\section{Referências}

AGUIAR, A. E. Produção de texto na escola - modo(s) de fazer. In: ARAÚJO, F; COSTA, I; MOREIRA, T. Gêneros textuais e ensino: propostas metodológicas de leitura e escrita. São Carlos: Pedro \& João Editores, 2020.

ALONSO, M. (Org.) O trabalho docente - teoria e prática. São Paulo: Pioneira, 2003. BAGNO, M. Preconceito linguístico: o que é, como se faz. São Paulo: Loyola, 1999.

BORTONI-RICARDO, S. M. Educação em língua materna: a sociolinguística na sala de aula. 6. Ed. São Paulo: Parábola, 2004.

BORTONI-RICARDO, S. M. Nós cheguemu na escola, e agora? Sociolinguística \& Educação. São Paulo: Parábola Editorial, 2005.

BORTONI-RICARDO, S. M. e MACHADO, V. R. (Orgs). Os doze trabalhos de Hércules - do oral para o escrito. São Paulo: Parábola, 2013.

BRASIL. Parâmetros Curriculares Nacionais (PCN) Língua Portuguesa. Brasília: MEC/Secretaria de Educação Básica, 1997.

BRASIL. Base Nacional Comum Curricular: Educação Infantil e Ensino Fundamental. Brasília: MEC/Secretaria de Educação Básica, 2017.

FISHMAN, J. A sociologia da Linguagem. In: FONSECA, M. S. V.; NEVES, Moema F. (orgs). Sociolinguística. Rio de Janeiro: Eldorado, 1974.

FREIRE, P. Pedagogia da indignação: cartas pedagógicas e outros escritos. São Paulo: Editora UNESP, 2000.

FUZA, A. F., et al. Concepções de linguagem e o ensino da leitura em língua materna. Linguagem \& Ensino, Pelotas, v.14, n.2, p. 479-501, jul./dez. 2011.

GADOTTI, M. Boniteza de um sonho: ensinar e aprender com sentido. Novo Hamburgo: Feevale, 2003.

GADOTTI, M. Histórias das ideias pedagógicas. 2 ed. São Paulo: Ática, 1994.

KLEIMAN, A. Processos identitários na formação profissional: o professor como agente de letramento. In: CORRÊA, M. L. G. e BOCH, F. (orgs.). Ensino de língua: representação e letramento. Campinas: Mercado de Letras, 2006. 
LABOV, W. Padrões Sociolinguísticos. São Paulo: Parábolas, [1972] 2008.

LUCKESI, C. C. Avaliação da aprendizagem escolar. 3 ed. São Paulo: Cortez, 1996.

MARIANI, B. Entre a evidência e o absurdo: sobre o preconceito linguístico. Cadernos de letras da UFF: preconceito linguístico e cânone literário, Niterói, v. 36, 2008.

MILROY, J. Ideologias linguísticas e as consequências da padronização. In: LAGARES, X. C.; BAGNO, M. Políticas da norma e conflitos linguísticos. Tradução de Marcos Bagno. São Paulo: Parábola Editorial, 2011. p. 49-87.

MORIN, E. Os sete saberes necessários à educação do futuro. São Paulo: Cortez, 2000.

PATTO, M. H. S. A produção do fracasso escolar: histórias de submissão e rebeldia. São Paulo: Casa do Psicólogo, 1999.

POSSENTI, S. Porque (Não) ensinar gramática na escola? Campinas, São Paulo: ALD: Mercado de Letras, 1996.

SAVIANI, D. Escola e democracia: teorias da educação, curvatura da vara onze teses sobre educação e política. 24 ed. São Paulo: Cortez: Autores Associados, 1991.

SIGNORINI, I. A questão da língua legítima na sociedade democrática: um desafio para a linguística aplicada contemporânea. In: MOITA LOPES, L.P. (Org). Por uma Linguística Aplicada Indisciplinar. São Paulo: Parábola, 2006. p.169-190

SOARES, M. Linguagem e escola: uma perspectiva social. 17 ed. São Paulo: Ática, 2001. TRAVAGLIA, L. C. Gramática e interação: uma proposta para o ensino de gramática no $1^{\circ}$ e $2^{\circ}$ graus. São Paulo: Cortez, 1997.

VYGOTSKY, L.S. A formação social da mente. São Paulo: Martins Fontes, 2007. 